\title{
Studi Antibodi Poliklonal Anti-TBC dan Potensinya sebagai Rapid Test Kit Pendeteksi TBC
}

\author{
Muzaijadah Retno Arimbi ${ }^{1^{*}}$ \\ Bagian Ilmu Penyakit Dalam Fakultas Kedokteran Universitas Wijaya Kusuma Surabaya ${ }^{1}$ \\ *e-mail: muzaijadaharimbi@gmail.com
}

\begin{abstract}
Abstrak
Kematian akibat penyakit Tuberkulosis (TB) sampai saat ini masih menjadi problem dunia walaupun berbagai metode telah dilakukan guna dapat diperoleh diagnostik yang cepat, dilakukan penangan dengan tepat, sehingga dapat menekan prevalensi TB. Penelitian ini bertujuan untuk membuat Isolasi protein dari serum penderita TBC paru dengan sputum BTA (+), melakukan Isolasi protein dari serum penderita TBC paru dengan sputum BTA (-), serta mengetahui tingkat spesifitas antibodi pada serum penderita TBC paru dengan sputum BTA (+) dan serum penderita TBC paru dengan sputum BTA (). Jenis penelitian yang digunakan adalah eksperimental laboratorik pada hewan coba tikus wistar dengan desain penelitian Control Group Post Test Design, Rancangan penelitian yang digunakan dengan pemberian 3 perlakuan berbeda pada Kelompok tanpa perlakuan sebagai kontrol, Kelompok yang diberi isolat protein dari serum penderita TB Paru dengan sputum BTA (+) sebagai kelompok 1 dan Kelompok yang diberi perlakuan dengan diberi isolat protein dari serum penderita TB Paru dengan sputum BTA (-) sebagai kelompok 2. Dari data yang terkumpul Setelah dilakukan dot blot, dilanjutkan pentabulasian hasil dot blot. Program CorelPhotopaint $X 4$ untuk mendapatkan data rerata derajad ketebalannoda hitam yang diperiksa pada nitrosellulose membrane. Data yang terkumpul diolah dengan menggunakan perangkat lunak ( software) statistik SPSS versi 11.5. Dari hasil uji elektroforesis sampel protein serum penderita TB Paru dengan BTA (+) dan protein dari serum penderita TB Paru dengan BTA (-), didapatkan protein spesifik dengan berat molekul $39 \mathrm{kDa}$. Dari hasil uji easternbloting protein serum 1 berasal dari penderita TB Paru dengan BTA (+) dan protein serum 2 berasal dari dari serum penderita TB Paru dengan BTA (-), terjadi reaksi positip antara antibodipoliklonal (anti $39 \mathrm{kDa}$ ) dengan protein serum penderita TB Paru dengan BTA (+), atau protein dari serum penderita TB Paru dengan BTA (-). Antibodi poliklonal anti TBC pada penelitian nampaknya cukup sensitip sebagai Rapid tes pendeteksi TBC, namun tidak spesifisitas yang dibuktikan dengan hasil perhitungan statistik memiliki significansi $>0,05$, sehingga Antibodi poliklonal anti TBC pada penelitian ini cukup sensitip, namun tidak spesifik digunakansebagai alat deteksi MTb
\end{abstract}

Kata kunci: Tuberkulosis, Protein spesifik, Antibodi poliklonal, Uji spesifitas

\section{Study of Anti-tuberculosis Polyclonal Antibody and Its Potential As A Rapid Test Kit for Tuberculosis Detection}

\begin{abstract}
Tuberculosis (TB) is one of the long-known diseases and is still the leading cause of death in the world. A variety of detection methods have been and are being implemented in order to suppress TB prevalence. The aim of this study was to isolate protein from serum pulmonary tuberculosis patients with sputum BTA $(+)$, isolate protein from serum pulmonary tuberculosis patients with sputum BTA (-), and to know the level of antibody specificity in serum pulmonary tuberculosis patients with sputum BTA (+) and serum pulmonary tuberculosis patients with sputum BTA (-). The type of research used was laboratory experimental in Wistar rat experimental animals with Control Group Post Test Design research design. The research design was used with 3 different treatment groups, ie Control Group (without treatment), Group I (treated with isolate protein from serum of Pulmonary TB patients with sputum BTA (+)), and Group II (treated with protein isolate from serum of Pulmonary TB patient with sputum BTA (-) From collected data After dot blot is complete, tabulation of diagnostic test result (dot blot.) To obtain a standard in assessing the results of dot in each of these studies used CorelPhotopaint X4 program to obtain accurate data about
\end{abstract}


the thickness of thin black spots (nilaimean) on the nitrocellulose membrane quantitatively. The data collected is processed using software (software) statistics SPSS version 11.5 From the electrophoresis test results of an exciting protein sample $m$ of Pulmonary TB patients with BTA (+) and protein from serum of Pulmonary TB patients with AFB (-), obtained specific protein with molecular weight of $39 \mathrm{kDa}$. From the serum 1 serum easternbloting test result from pulmonary TB patients with BTA (+) and serum 2 protein derived from serum of Pulmonary TB patients with BTA (-), positive reaction occurred between antibodipoliklonal (anti $39 \mathrm{kDa}$ ) and serum protein of Pulmonary TB with BTA (+), or proteins from serum patients with pulmonary TB with AFB (-). The anti-tuberculosis polyclonal antibody in the study appears to be quite sensitive as Rapid tuberculosis detection test, but no specificity as evidenced by statistical calculation has significance $>0.05$, so the anti-tuberculosis polyclonal antibody in this study is quite sensitive, but not specifically used as an MTb detection device

Keywords: tuberculosis, specific protein, polyclonal antibody, specificity test

\section{PENDAHULUAN}

Kematian akibat penyakit Tuberkulosis sampai saat ini masih menjadi problem dunia walaupun berbagai metode telah dilakukan guna dapat diperoleh diagnostik cepat telah lama dikenal dan sampai saat ini masih menjadi pdan tepat, sehingga dapat dilakukan penanganan dengan cepat dan tepat. Setiap tahun, 8,74 juta didiagnosis sebagai TB aktif dengan angka kematian 2 juta per tahun. WHO mengumumkan darur global pada penyakit Tuberkulosis, akibat sebagian besar negara dijumpai kejadian tak terkendali pada penyakit dengan perhatian utama pada ketidak berhasilan terapi tuberkulosis dengan sputum BTA positif merupakan penderita berpotensi menular. Kasus TB dan kematian akibat TB 90\% dijumpai di negara berkembang yang menginfeksi usia produktif (15 - 50 tahun) dengan angka lebih dari $75 \%(1,2,3)$.

Kriteria menetapkan dugaan TB yang dikenal saat ini diantaranya pewarnaan tahan asam. Metode pewarnaan ini hasilnya kurang sensitif, oleh sebab jumlah $>10^{3}$ organisme / ml sputum, merupakan nilai minimal agar diperoleh hasil sputum BTA positif. Mycobacterium tuberkulosis (M. tuberculosis) akan memberikan gejala apabila individu terpapar paling cepat 5 minggu setelah terinfeksi, sehingga diagnosis TB didasarakan atas gejala klinis dan gambaran radiologis yang dikonfirmasi hapusan dan kultur sputum butuh waktu 2 bulan, sehingga terjadi kelambatan diagnosis dan terapi. Akibat ketidak sensitifan pewarnaan sputum BTA dan lambatnya perolehan hasil kultur sputum BTA, maka dibutuhkan imunodiagnosis yang mudah, cepat diperoleh hasilnya dan murah, sehingga dapat dipergunakan mendeteksi adanya tuberkulosis paru.

Tujuan dari penelitian ini adalah untuk mendapatkan protein spesifik dari serum penderita TBC paru dengan sputum BTA (+) dan protein spesifik dari serum penderita TBC paru dengan sputum BTA (-) yang dibuat antibodi poliklonal guna keperluan deteksi Tuberculosis secara cepat dan akurat dengan metode imunodiagnostik pada penderita Tuberculosis paru aktif.

\section{METODE PENELITIAN}

\section{Rancangan Penelitian}

Rancangan penelitian eksperimental laboratorik pada hewan coba tikus wistar dengan desain penelitian Control Group Post Test Design.

\section{Populasi dan Sampel}

Rancangan penelitian yang digunakan dengan pemberian 3 perlakuan berbeda, yaitu Kelompok tanpa perlakuan sebagai kontrol, Kelompok yang diberi isolat protein dari serum penderita TB Paru dengan sputum BTA (+) sebagai kelompok 1 dan Kelompok yang diberi perlakuan dengan diberi isolat protein dari serum penderita TB Paru dengan sputum BTA (), sebagai kelompok 2

\section{Prosedur Penelitian}

Prosedur Penelitian ini dibagi menjadi 3 tahap yakni tahap Isolasi protein kasar, pembuatan antibodi monoklonal dan Uji spesifisitas.

\section{Tahap Isolasi protein kasar}

Isolasi protein dilakukan dari 2 sumber yakni serum penderita TB Paru BTA (+) dan serum penderita TB Paru BTA (-). Isolasi pada 
darah pasien dilakukan dengan pengambilan darah pasien melalui vena. Darah yang terkumpul segera di sentrifuse pada kecepatan 2000 g selama 4 menit pada suhu $4^{\circ} \mathrm{C}$, serum yang telah terbentuk dipisahkan dan dianalisa kadar proteinnya menggunakan spektrofotometri pada panjang gelombang 280 $\mathrm{nm}$. Hasil absorbansi masing- masing yang telah diketahui, ditentukan rumus kadar proteinnya, selanjutnya sejumlah antigen diberikan secara intramuscular dihitung berdasar kandungan protein 200 mikrogram secara intramuscular pada tiap pemberian. Sebelum pembuatan antibodi terlebih dahulu protein dari serum penderita TB paru BTA (+) dan serum penderita TB paru BTA (-) dianalisa berat molekulnya dengan elektroforesis SDS PAGE. Elektroforesis SDS-PAGE $12.5 \%$ diterapkan pada protein dari serum. Tiga tahap yang dilakukan dalam SDSPAGE, antara lain: persiapan gel, injeksi sampel dilanjutkan proses pewarnaan dan pencucian gel. Tahap persiapan gel, berupa pembuatan 2 macam gel, yaitu gel yang dipergunakan sebagai tempat pengumpul sampel (stacking gel) dan gel akrilamid merupakan media yang berguna untuk pemisahan protein (separating gel). Campuran separating gel dituangkan dalam plate (wadah untuk lapisan gel) menggunakan mikropipet. Campuran stacking gel yang terbentuk dituang dipermukaan separting gel dengan sisir yang terpasang, selanjutnya ditunggu 30 menit sampai terbentuk gel. Selanjutnya sisir diangkat, plate dipasang pada alat elektroferesis dan running buffer dituangkan kedalam bejana elektroforesis. RSB (1:1) ditambahkan pada sampel, dipanaskan suhu $100{ }^{\circ} \mathrm{C} 5$ menit, selanjutnya diinjeksikan 5 $\mu \mathrm{L}$ pada tiap sumuran. Dengan arus konstan 20mA dan tegangan 100 Volt dilakukan Running sampai sampel berlokasi $0.5 \mathrm{~cm}$ diatas dasar gel. Hasil running gel dilakukan perendaman 30-60 menit dalam larutan staining, selanjutnya dilakukan perendaman sampel dalam larutan destaining yang digerakkan dengan digoyang berkali-kali / didiamkan selama 24 jam agar warna gel larut, selanjutnya gel ditutup filter paper, selanjtnya dihasilkan dilakukan scanning. Protein standar untuk mengukur massa molekul relatif, sehingga nilai protein serum dapat diperoleh, selanjutnya persamaan regresi linier dengan harga log massa molekul dibuat pada posisi sumbu y dengan harga Rf dibuat pada posisi sumbu x. Harga Rf (Retardaction factor) digunakan rumus: $\mathrm{Rf}=$ (Jarak pergerakan protein dari tempat awa I / Jarak pergerakan warna dari tempat awal)

\section{Tahap Pembuatan antibodi poliklonal}

Antibodi poliklonal Mycobacterium Tuberculosis diperoleh dari serum tikus wistar yang imunisasi dengan protein serum penderita TB Paru dengan sputum BTA $(+)$ dan protein dari serum penderita dengan sputum TB Paru BTA (-). Pada kelompok kontrol diimunisasi dengan Complette Freund's Adjuvant (CFA) tanpa antigen sebanyak $100 \mu \mathrm{l}$. Pada kelompok kedua dan ketiga, diinjeksi dengan protein serum penderita TB Paru sputum BTA $(+)$ dan protein dari serum penderita TB Paru sputum BTA (-) dengan campuran antigen sebesar $200 \mu \mathrm{g} /$ injeksi berat badan. Perbandingan Antigen dan CFA 1:1 dihomogenisasi sehingga terbentu emulsi putih. 2 minggu kemudia injeksi booster dilakukan. Sedangkan pada kontrol diinjeksi IFA (Incomplette Freund's Adjuvant) tanpa antigen sebanyak $100 \mu \mathrm{l}$. Kelompok dua dan tiga masingmasing dilakukan imunisasi dengan protein serum penderita TB Paru dengan sputum BTA (+) dan protein dari serum penderita TB Paru dengan sputum BTA (-) diemulsikan dengan IFA 1:1. Setelah mencapai 2 minggu dilakukan pengambilan darah tikus, selanjutnya darah yang terkumpul diambil serumnya dengan cara sentrifuse pada kecepatan 3000 rpm, 10 menit dan suhu $4^{\circ} \mathrm{C}$. Selanjutnya serum dipipet kedalam tabung eppendorf untuk difreezer sampai purifikasi serum tiba. Purifikasi serum memakai ammonium sulfat jenuh 50\% dan ammonium sulfat dengan perbandingan 1:1, selanjutnya sebanyak 3 kali dilaksanakan vortex tiap 10 menit pada suhu $4^{\circ} \mathrm{C}$, serum selanjutnya disentrifugasi $3000 \mathrm{rpm}$ selama 20 menit pada suhu $4^{\circ} \mathrm{C}$, setelah supernatan dibuang presipitat dipipet dan ditambah dengan ammonium sulfat 1:10, disentrifugasi $3000 \mathrm{rpm}, 20$ menit pada suhu $4^{\circ} \mathrm{C}$. Supernatan dibuang, selanjutnya presipitat dilarutkan menggunakan buffer fosfat 0,05 M pH 7 (1:1). Setelah divortex, serum dipipet dan dimasukkan dalam selofan dan didialisis dengan $0,01 \mathrm{M}$ buffer fosfat $\mathrm{pH} 7$ pada suhu rendah selama 12 jam.

\section{Tahap Uji Spesifisitas}

Estern blot atau Dot blot merupakan uji serologis berfungsi sebagai deterktor spesifisitas antigen dan antibodi. Antibodi yang dibuat dicampurkan dalam PBS dengan kandungan NaN3 ( berupa $1 \mathrm{~mL}$ Na-Azida $9 \mathrm{~mL}$ PBS) 
dipipetkan pada membran nitroselulosa yang dibasahi dengan larutan PBS. Selanjutnya membran dipasangkan pada alat dot blotter, kemudian sampel disentuhkan sebanyak 50 $\mu$, alat dot blotter dijalankan sampai antigen terserap dalam membran, selanjutnya dibloking dengan buffer 1 jam dan pencucian dengan PBS Tween-20 0,05\% sebanyak 3 kali. Selanjutnya hasil blotter diinkubasi dengan antibodi primer dalam PBS-Skim Milk 1\% selama 2 jam, dicuci dengan PBS Tween-20 0,05\% diulang sebanyak 3 kali. Selanjutnya hasil diinkubasi ulang dengan antibodi sekunder Igg AP (Alkaline Phosphatase) dalam waktu 1 jam, kemudian dicuci kembali dengan PBS Tween-20 pengulangan sebanyak 3 kali. Hasil diinkubasikan dalam substrat BCIP dalam ruang gelap, sehingga diperoleh perubahan warna pada hasil akhir, dilakukan penambahan aquades untuk menghentikan proses, selanjutnya membran diambil dari mesin dot blotter dan dikeringkan pada udara terbuka.

\section{Analisa Data}

Proses dot blot yang telah selesai, ditabulasi hasil uji diagnostiknya. Nilai standard diperoleh dengan menilai hasil dot dalam setiap penelitian untuk memperoleh data akurat berupa nila rerata ketebalan noda hitam pada membran nitroselulosa dengan menggunakan program Corel Photopaint X4 . Data yang terkumpul diolah dengan menggunakan perangkat lunak ( software) statistik SPSS versi 11.5 .

\section{HASIL PENELITIAN}

\section{Isolasi Protein Kasar}

Hasil uji elektroforesis sampel protein serum penderita TB Paru dengan BTA $(+)$ dan protein dari serum penderita TB Paru dengan BTA (-), didapatkan protein spesifik dengan berat molekul $39 \mathrm{kDa}$.

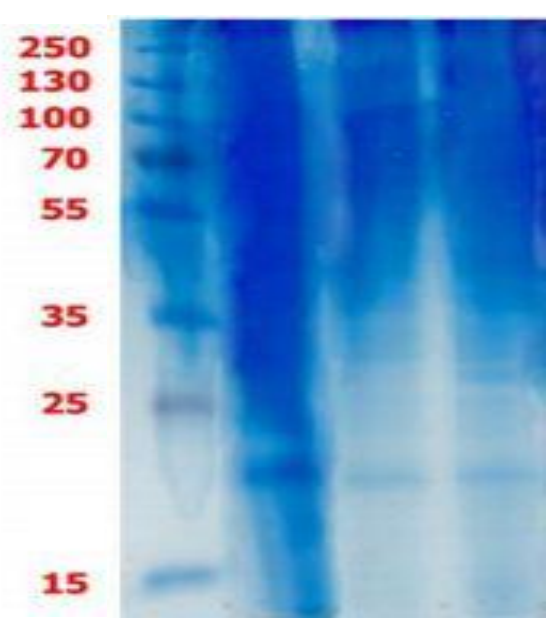

Gambar 1. Elektroforesis serum penderita TB Paru

\section{Uji Spesifitas}

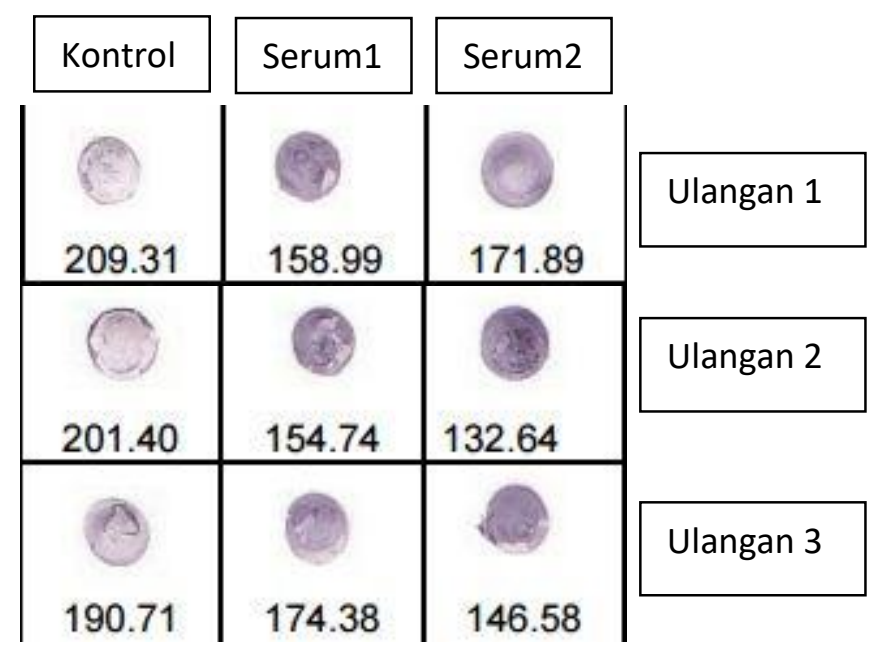

Hasil uji Eeastern bloting protein serum 1 berasal dari penderita TB Paru dengan BTA (+) dan protein serum 2 berasal dari serum penderita TB Paru dengan BTA (-), terjadi reaksi positip antara antibodipoliklonal (anti $39 \mathrm{kDa}$ ) dengan protein serum penderita TB Paru dengan BTA $(+)$, maupun protein dari serum penderita TB Paru dengan BTA (-) 
ISSN 1978-2071 (Print); ISSN 2580-5967 (Online)

Jurnal Ilmiah Kedokteran Wijaya Kusuma 5(2) : 11-17

\section{Analisa Data Hasil Penellitian}

\section{ANOVA}

spesifitas
\begin{tabular}{|l|l|r|r|r|r|}
\hline & $\begin{array}{l}\text { Sum of } \\
\text { Squares }\end{array}$ & df & Mean Square & F & Sig. \\
\hline Between Groups & 1636,788 & 2 & 818,394 & 1,601 &, 234 \\
Within Groups & 7666,815 & 15 & 511,121 & & \\
Total & 9303,603 & 17 & & & \\
\hline
\end{tabular}

Hasil Uji Anova untuk spesifisitas Antibodi Poliklonal terhadap antigen MTB dalam serum penderita TB Paru dengan BTA (+) / kelompok 1 maupun serum penderita TB Paru dengan BTA (-) /kelompok 2 dibanding kelompok kontrol dengan nilai signifikansi > 0,05 , maka tidak ada beda antara kelompok kontrol dengan kelompok 1 dan kelompok 2

Multiple Comparisons

Dependent Variable: spesifitas

LSD

\begin{tabular}{|c|c|c|c|c|c|c|}
\hline \multirow[b]{2}{*}{ (I) kelompok } & \multirow[b]{2}{*}{ (J) kelompok } & \multirow{2}{*}{$\begin{array}{c}\text { Mean } \\
\text { Difference } \\
(I-J)\end{array}$} & \multirow[b]{2}{*}{ Std. Error } & \multirow[b]{2}{*}{ Sig. } & \multicolumn{2}{|c|}{$95 \%$ Confidence Interval } \\
\hline & & & & & Lower Bound & Upper Bound \\
\hline \multirow[t]{2}{*}{ kontrol } & serum 1 & 12,68333 & 13,05273 & ,347 & $-15,1379$ & 40,5046 \\
\hline & serum 2 & 23,32833 & 13,05273 & ,094 & $-4,4929$ & 51,1496 \\
\hline \multirow[t]{2}{*}{ serum 1} & kontrol & $-12,68333$ & 13,05273 & ,347 & $-40,5046$ & 15,1379 \\
\hline & serum 2 & 10,64500 & 13,05273 & ,428 & $-17,1762$ & 38,4662 \\
\hline \multirow[t]{2}{*}{ serum 2} & kontrol & $-23,32833$ & 13,05273 & ,094 & $-51,1496$ & 4,4929 \\
\hline & serum 1 & $-10,64500$ & 13,05273 & ,428 & $-38,4662$ & 17,1762 \\
\hline
\end{tabular}

Hasil Multiple Comparasi LSD untuk spesifisitas Antibodi Poliklonal terhadap antigen MTB nampak pada kelompok kontrol dibanding kelompok perlakuan 1 /serum 1 memiliki mean $(12,683 \pm 13,053)$ dengan significansi 0,347; kelompok kontrol dibanding kelompok perlakuan 2 /serum 2 memiliki mean (23,328 \pm $13,053)$ dengan significansi 0,094 ; sedangkan kelompok perlakuan 1 /serum 1 dibanding kelompok perlakuan 2 /serum 2 memiliki mean $(10,645 \pm 13,053)$ dengan significansi 0,428 .

\section{PEMBAHASAN}

Deteksi keberadaan antigen di dalam tubuh dilakukan oleh antibodi. Pembuatan antibodi secara konvensional dapat dilakukan dengan cara vaksinasi hewan coba, kemudian mengisolasi antibodi dalam serum hewan coba, sehingga diperoleh antibodi poliklonal. Antibodi poliklonal dalam jumlah besar dapat diperoleh dengan melakukan vaksin pada binatang coba dengan jumlah yang banyak sesuai dengan kebutuhan vaksin, sehingga jumlah antibodi poliklonal dirasakan sangat kurang. Antibodi spesifik dapat dibuat secara in vitro, sehingga antibodi dapat diproduksi dalam jumlah besar tanpa terkontaminasi dengan antibodi lain yang tidak diinginkan. Antibodi spesifik yang diperoleh dari Antibodi poliklonal jumlahnya sangat sedikit dan bersifat heterogen karena antibodi poliklonal mengikat berbagai macam epitop, sehingga sangat sulit menghilangkan antibodi lain yang tidak diinginkan (4). Sedangkan Antibodi monoklonal, merupakan antibodi homogen, diperoleh dari satu klon sel hibrid yang dibuat dengan imuniasasi pada hewan coba, selanjutnya sel limfosit hewan coba difusikan dengan sel mieloma, sehingga sel hibrid yang diperoleh dapat dibiakkan (immortal). Spesifisitas Antibodi monoklonal lebih besar dibanding antibodi poliklonal, karena 1 epitop antigen saja yang dapat diikat Antibodi monoklonal, sehingga antibodi jenis ini dapat dibuat dalam banyak. Antibodi 
monoklonal dibuat dengan penggabungan dua jenis sel, yakni sel limfosit B sebagai penghasil antibodi dan sel mieloma sebagai sel yang membelah tak terkendali, dengan hasil penggabungan yang dikenal sebagai hibridoma (5)

Diagnosis TB Paru pada penderita ditegakkan berdasarkan hasil sputum smear Batang Tahan Asam (BTA) dan berdasarkan gambaran pada Thoraks foto. Diagnosis akhir yang diperoleh yaitu Penderita yang terdiagnosis secara klinis (gambaran pada foto thoraks adanya fibroinfiltrat/infiltrat dengan sputum smear BTA negatif), serta Penderita yang terdiagnosis secara bakteriologi (gambaran foto thoraks adanya fibroinfiltrat/infiltrat dengan sputum smear BTA positip). Kuman MTB pada sputum penderita TB Paru terdeteksi apabila jumlahnya mencukupi, yaitu $>10^{3}$ organisme/ml sputum (TB Update,2017). Pada penelitian ini dipergunakan Antibodi poliklonal yang diharapkan dapat menjadi rapid test kit sebagai pendeteksi kuman MTB. Antibodi Poliklonal pada penelitian ini diperoleh dari 2 kelompok, yaitu kelompok 1 adalah serum tikus coba yang di vaksin Isolat protein serum penderita TB Paru aktif dengan sputum BTA (+) dan kelompok 2 adalah serum tikus coba yang di vaksin Isolat protein dari serum penderita TB Paru aktif dengan sputum BTA (-).

Kilas balik dari perjalanan kuman MTB dalam tubuh diawali dari masuknya kuman kedalam saluran napas sampai pada alveoli, selanjutnya kuman MTB ditangkap oleh makrofag dan masuk ke dalam endosom makrofag yang diperantarai reseptor manosa makrofag, sehingga makrofag mengenali glikolipid berselubung manosa di dinding sel MTB, selanjutnya MTB menghambat respon mikrobisida normal dengan cara manipulasi $\mathrm{pH}$ dan penghentian pematangan endosom. Akibat terganggunya pembentukan fagolisosom efektif oleh makrofag, maka MTB leluasa berproliferasi dalam makrofag alveolus tanpa gangguan sampai terjadi bakterimia dan penyebaran luas ke berbagai tempat. Oleh sebab itu mengapa Isolat protein dari serum penderita TB Paru dapat dijumpai baik yang dalam sputumnya terdeteksi adanya kuman MTB maupun tidak terdeteksi adanya kuman MTB (Pedoman Nasional Pengendalian Tuberkulosis, 2014). Spesifisitas tes serologis awal yang dibuat dari antigen kasar adalah rendah, karena reaksi silang dengan spesies Mycobacterium lingkungan. Spesifisitas dapat ditingkatkan dengan menggunakan antigen yang dimurnikan. Berbagai antigen telah terjadi disesuaikan dengan serodiagnosis TB. Antigen tertentu adalah ditemukan memiliki signifikansi lebih diagnostik, salah satunya, $38 \mathrm{kDa}$ antigen yang merupakan protein pengikat fosfat, dilaporkan spesifik untuk kompleks $M$. tuberculosis. Antigen ini telah diidentifikasi sebagai reagen potensial digunakan untuk skrining TB (8). Pada penelitian ini Protein Isolat diperoleh dari serum penderita TB Paru dengan sputum BTA (+) maupun BTA (-) dengan berat molekul 39 kDa.

Spesifisitas adalah kemampuan dalam mendeteksi pada individu yang memiliki keadaan khusus (misalnya: penyakit tertentu), dibanding kesalahan dalam pengelompokan sejumlah individu sehat sebagai individu yang sakit. Spesifisitas adalah kemampuan mendeteksi negatif sejati, sehingga spesifisitas yang besar, artinya individu dengan penyakit tertentu akan menunjukan hasil positif dengan pemeriksaan (tes) tertentu, sehingga peningkatan hasil positif palsu, dimana individu sehat terdeteksi sebagai individu sakit (9). Sensitivitas adalah kemampuan mendeteksi pada individu yang memiliki keadaan khusus (misalnya: penyakit tertentu) tanpa meloloskan beberapa individu sakit. Peningkatan hasil negatif palsu, akan menurunkan sensitivitas, sehingga sejumlaj negatif palsu akan mengurangi sensitivitas (9).

Pada penelitian ini Kelompok kontrol yang diimunisasi dengan CFA (Complette Freund's Adjuvant) $100 \mu \mathrm{l}$, dibanding kelompok 1, yaitu: tikus coba yang diimunisasi dengan isolat protein serum penderita TB Paru aktif dengan sputum BTA (+) maupun kelompok 2, yaitu: tikus coba yang diimunisasi dengan isolat protein serum penderita TB Paru aktif dengan sputum BTA (-) memiliki nilai signifikansi 0,234 (nilai sig $>0,05)$, artinya tidak dijumpai beda signifikansi antara kontrol, perlakuan 1 dan perlakuan 2. Hal ini terjadi diduga akibat lemahnya antibodi poliklonal dalam perolehan antibodi spesifik, karena antibodi yang diperoleh secara poliklonal kemungkinan besar terkontaminasi dengan antibodi lain yang tidak dikehendaki, sehingga antibodi yang spesifik untuk MTB jumlahnya sangat sedikit. Heterogenitas antibodi terjadi akibat banyaknya antibodi kurang spesifik dalam kemampuannya mengikat berbagai epitop, akibatnya tidak mudah menghilangkan antibodi lain yang tidak diinginkan. Pada penelitian pengamatan perbedaan warna gumpalan antigen antibodi dari hasil uji Estern blooting 
kelompok perlakuan lebih pekat/warna lebih biru ke unguan artinya kandungan proteinnya lebih tinggi dibanding kelompok kontrol, sehingga secara kualitatif warna gumpalan isolat protein penderita TB paru sebagai antigen yang berrespon terhadap antibodi poliklonal tikus coba, sehingga dikatakan bahwa hasil penelitian ini cukup sensitive. Disimpulkan bahwa Antibodi poliklonal anti TBC pada penelitian ini nampaknya cukup sensitip, namun tidak spesifik digunakan sebagai sebagai alat deteksi MTB

\section{KESIMPULAN DAN SARAN}

Pada penelitian telah didiperoleh isolat

\section{DAFTAR PUSTAKA}

1. Departemen Kesehatan Republik Indonesia, 2002. Pedoman nasional penanggulangan tuberkulosis, cetakan VI, Jakarta.

2. Kumaresan PR, Lai WC, Chuang SS, Bennett, M, Mathew PA, 2002. CS1, a novel member of the CD2 family, is hemophilic and regulates NK cell function. Mol Immunol. 39(1-2): 1-8

3. Blanc L, Chaulet P, Espinal M, et al, 2003. Treatment of tuberculosis. Guidelines for national programmes $3^{\text {rd }}$ ed. World Health Organization, Geneva.

4. Gordon S, 2008. Elie Metchnikoff : Father of natural immunity. Eur. J. Immunol. 38 (12): 3257-3264. Köhler G and Milstein C, 1975. Continuous cultures of fused cells secreting antibody of predefined specificity. Nature. 256 (5517): 495-497.

5. Köhler G and Milstein C, 1975. Continuous cultures of fused cells secreting antibody of predefined specificity. Nature. 256 (5517): 495-497. protein spesifik dari protein serum penderita TB Paru dengan BTA (+) dan BTA (-) dengan berat molekul $39 \mathrm{kDa}$. Uji spesifitas protein ini menunjukkan hasil positif sebesar rerata 162,703 pada protein serum penderita TB Paru dengan BTA (+) serta sebesar rerata 150,37 pada protein dari serum penderita TB Paru dengan BTA (-). Antibodi poliklonal anti TBC pada penelitian nampaknya cukup sensitip sebagai Rapid tes pendeteksi TBC, sehingga antibodi poliklonal anti TBC pada penelitian ini cukup sensitip, namun tidak spesifik digunakan sebagai sebagai alat deteksi MTB

6. TB UPDATE IX, 2017. Novel Management to end TB. Proceeding Book. Workshop, Simposium, Pameran. Hotel Bumi Surabaya, 29-30 April. Departemen Pulmonologi dan Ilmu Kedokteran Respirasi, FK-Unair RSUD Dr. Soetomo Surabaya

7. Pedoman Nasional Pengendalian Tuberkulosis, 2014. Indonesia Bebas Tuberkulosis. Kementerian Kesehatan Republik Indonesia Dirjen Pengendalian Penyakit dan Penyehatan Lingkungan.

8. Pfyffer GE, Brown-Elliot BA, Wallace WC Jr, 2003. Mycobacterium : General Characteristics, Staining Procedures. Manual of Clinical Microbiology Volume 1, 8th edition. Edited by: Murray PR, Baron EJ, Jorgensen JH, Pfaller MA, Yolken RH. Washington, DC: ASM Press; 532-559.

9. Sharma SK, Kohli M, Yadav RN, Chaubey J, Bhasin D, Sreenivas V et al, 2015. Evaluating the Diagnostic Accuracy of Xpert MTB/RIF Assay in Pulmonary Tuberculosis. PLOS One. 10(1): 1-9 